\title{
Ecological Stoichiometric Characteristics of Soil at Different Depths in a Karst Plateau Mountain Area of China
}

\author{
Yanghua Yu*, Yongkuan Chi \\ School of Karst Science, Guizhou Normal University / State Engineering Technology Institute \\ for Karst Decertification Control, Guiyang, P. R. China
}

Received: 18 December 2018

Accepted: 12 January 2019

\begin{abstract}
The study of soil ecological stoichiometry has mainly focused on surface soils. Exploring the nutrient content and stoichiometric characteristics of deep soils in karst areas helps us to understand the intrinsic relation mechanism and provides scientific evidence for making full use of fractured soil. We analyzed soil nutrient content, nutrient supply intensity, stoichiometric ratios, and their inter-relations at different soil depths in a karst plateau mountain area of China. Soil nutrient supply capacity was relatively low in the study area. The nitrogen and potassium supply capacity was highest in the surface layer, while phosphorus supply capacity was highest in deep soil. Carbon, nitrogen, phosphorus and potassium made varying contributions to the ecological stoichiometric ratios. Soil nitrogen and phosphorus were found to be deficient in the karst plateau mountain area of China. There was certain coordination between nutrient supply intensity and ecological stoichiometric ratios.
\end{abstract}

Keywords: geological environment,soil and plants, soil nutrient, southwest China

\section{Introduction}

Plants are the source of life in the living world. They perform many ecological functions in their environment, and they shape the life of living things in the environment where they live. The life of living things in the world is directly or indirectly dependent on plants. The ability of plants to fulfil their functions primarily depends on the availability of appropriate climatic and edaphic conditions. Therefore, soil is one of the absolutely necessary conditions for plant

*e-mail: yuyanghua2003@163.com existence, which is essential for the life of living things. The soil is defined as "the part of the solid earth that has been altered by the loosening of the earth, humus formation and chemical decomposition, by the transport of humidification and chemical decomposition products". However, when it is examined in detail, the soil is a very complex structure and the biological and biochemical process in the soil is the basis of the terrestrial ecosystem. In this respect, it is very important to examine the structural change of the soil and to determine its relationship with the plant. Some studies shows that it examined the change of the soil structure in the forests according to the tree species. An attempt to determine some soil characteristics based on tree species and depth of soil was made within the scope of the study [1-7]. 
Ecological stoichiometry is the study of the chemical element balance and energy balance in ecosystems. It combines different aspects of research theory in ecology, with the aim to study the content and proportional relations of chemical elements and their variation patterns with environmental factors, and explore the balance and coupling relationships between different elements [8-11]. Ecological stoichiometry has been widely used in the study of ecosystem productivity and material cycling. Carbon (C), nitrogen $(\mathrm{N})$, phosphorus $(\mathrm{P})$, and potassium $(\mathrm{K})$ are the basic chemical elements for plant growth and play major roles in the body construction and physiological regulation of plants [12], all these elements are derived from the soil. Soil nutrient elements are coupled to each other during their cycling [13] and this makes it necessary to understand the proportional relationship between various elements [12] and explore the balance between different nutrients. Therefore, study of the ecological stoichiometric characteristics of soil nutrients can reveal nutrient availability, which has great implications for understanding the cycling and balance mechanisms of $\mathrm{C}, \mathrm{N}, \mathrm{P}$ and $\mathrm{K}$, provides a new approach toe valuating the suitability of organisms, and plays a key role in enriching the stoichiometric characteristics of ecosystems.

Since the Redfield ratio was proposed in 1958 [14], there has been a large amount of research focusing on measurement of ecological stoichiometric ratios. There are wide applications in many fields such as the determination of limiting nutrient elements [15], biological production [16], nutrient cycling [17], litter decomposition[18], and nutrient distribution [19]. These are of great importance for revealing the influencing factors of the ecosystem process and their mechanism of action, and also provide scientific evidence for understanding the biogeochemical cycle of nutrient elements. In recent years, researchers have studied the stoichiometric characteristics of soils [20-21], and existing results have laid a foundation for exploration of soil nutrient supply conditions, determination of limiting elements, and evaluation of soil quality. However, these studies mainly focused on the surface soil, and the ecological stoichiometric variation patterns in deep soil have rarely been investigated. Exploration of the stoichiometric characteristics of soils from different depths is therefore needed to increase understanding of soil nutrient stoichiometry as a whole.

In this study, we selected the soil from $0-400 \mathrm{~cm}$ depth in a karst rocky area of China subject to desertification and analyzed the $\mathrm{C}, \mathrm{N}, \mathrm{P}$, and $\mathrm{K}$ contents. The vertical distribution patterns of $\mathrm{C}, \mathrm{N}, \mathrm{P}$, and $\mathrm{K}$ were explored using ecological stoichiometry to determine the ecological stoichiometric characteristics of $\mathrm{C}, \mathrm{N}, \mathrm{P}$, and $\mathrm{K}$ in the soil of different depths in the same profile, and assess the intrinsic relationship of soil stoichiometric characteristics at different depths. The results of this study will help us understand the variation patterns of soil nutrients and their ecological stoichiometric characteristics in karst plateau mountain areas. Moreover, these findings will provide an important theoretical reference for the conservation of this ecosystem, which is reliant on the comprehensive management and utilization of nutrients.

\section{Materials and Methods}

\section{Study Area Description}

The study area is located in a tributary area

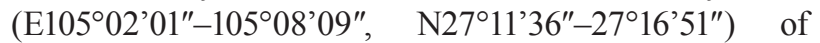
the Liuchong River Basin in western Bijie, Guizhou Province, China. This area lies in a karst plateau mountain environment, with an average annual rainfall of $863 \mathrm{~mm}$ and an annual average temperature of $\sim 14^{\circ} \mathrm{C}$. The landforms are diverse and the terrain is fragmented. Cultivated land is mostly distributed on slopes, terraces, and in mountain valleys, often forming terrace fields around mountains and dam fields in valleys. There are above ground and underground rivers, funnels, blind valleys, sinkholes, skylights, and karst depressions. Regional vegetation mainly comprises coniferous and broad-leaved mixed forest; however, dry land vegetation has gained an advantage under long-term human disturbance. The major soil type is yellow soil, with mountain yellow brown soil and calcareous soil being found in some areas [22].

The plant community type at the sampling site is Platycarya longipes and Carpinus kweichowensis deciduous shrub land. The major shrub species are $P$. longipes, C. kweichowensis, Castanea mollissima,Mahonia, Quercus variabilis, Cyclobalanopsis glauca, and polygnoi multiflori. The major herbs are Lysionotus pauciflorus Maxim, Festuca elata Keng, Carex capilliformis, Clematis quinquefoliolata, Galium asperuloides, and Imperata cylindrical.

The soil samples in this article are highly representative for the following reasons: (1) In karst plateau mountain area, because of high heterogeneity, complexity and variability of its underground habitats, it is difficult to collect the soil samples in deep vertical fractures, and the soil samples with continuous and intact soil-forming process. (2) The sampling points have typical topography and surface vegetation, which can reveal the interactions among geological environments, soil and plants, and also can represent the basic characteristics of over ground and underground spaces in this area. (3) The soil nutrient content, which combines the effects of rock weathering, plant root decomposition and soil erosion or accumulation, can express the features of parent materials, biology and time in a soil-forming process in a karst plateau mountain area. 


\section{Sample Collection}

When new soil was exposed by an excavator, we removed the humus layer and selected a profile down to $400 \mathrm{~cm}$ soil depth. The soil profile was divided into $40 \mathrm{~cm}$ intervals and samples were taken from 10 layers (i.e., 0-40, 40-80, 80-120, 120-160, 160-200, 200-240, 240-280, 280-320, 320-360, and 360-400 cm). Multi-point sampling was performed and the samples were thoroughly mixed. The collected soil samples were naturally air dried, ground, and sieved before being used for nutrient analysis.

\section{Sample Analysis}

Soil organic carbon (SOC) was determined by the potassium dichromate oxidation external heating method (NY/T 1121.6-2006). Total $\mathrm{N}$ was determined by the semi-micro Kjeldahl method after $\mathrm{HClO}_{4}-\mathrm{H}_{2} \mathrm{SO}_{4}$ digestion. Available $\mathrm{N}$ was determined by the alkali dissolution method. Total P was analyzed colorimetric ally by the ammounium molybdate method. Available $\mathrm{P}$ was determined using the $\mathrm{NH}_{4} \mathrm{~F}-\mathrm{HCl}$ extraction, molybdenum antimony colorimetry, ultraviolet spectrophotometry approach. Total $\mathrm{K}$ was determined by $\mathrm{HF}-\mathrm{HNO}_{3}-\mathrm{HClO}_{4}$ digestion-flame photometry (GB 9836-88).Available Kwas extracted using a neutral ammonium acetate solution and analyzed by flame photometry.

\section{Data Processing and Statistical Analysis}

The nutrient supply intensity was calculated as the ratio of available to total nutrients expressed as a percentage [23]. Data preprocessing and preliminary calculations were performed using Excel2007 (Microsoft Corp., Redmond, WA, USA). Data were analyzed using SPSS21.0 (IBM SPSS, Somers, NY, USA). SOC, N, $\mathrm{P}$, and $\mathrm{K}$ contents and their stoichiometric ratios were subjected to one-wayanalysis of variance (ANOVA). Correlations between SOC, N, P, and K contents and their stoichiometric ratios were evaluated by Pearson correlation analysis. Soil stoichiometric ratios were expressed as the mass ratio [24]. Data in tables and figures are presented as means \pm standard deviation. The significance level was set to $p=0.05$. Figures were created using Origin 8.5.1 (Origin Lab Corp., Northampton, MA, USA).

\section{Results}

\section{Nutrient Contents of Soil at Different Depths}

The SOC, total N, total $\mathrm{P}$, and total $\mathrm{K}$ contents of soil at different depths are presented in Fig. 1. SOC, total $\mathrm{N}$, total $\mathrm{P}$, and total $\mathrm{K}$ showed different patterns of variation with increasing soil depths. SOC varied between 0.48 and $7.17 \mathrm{mg} \mathrm{g}^{-1}$, and was generally

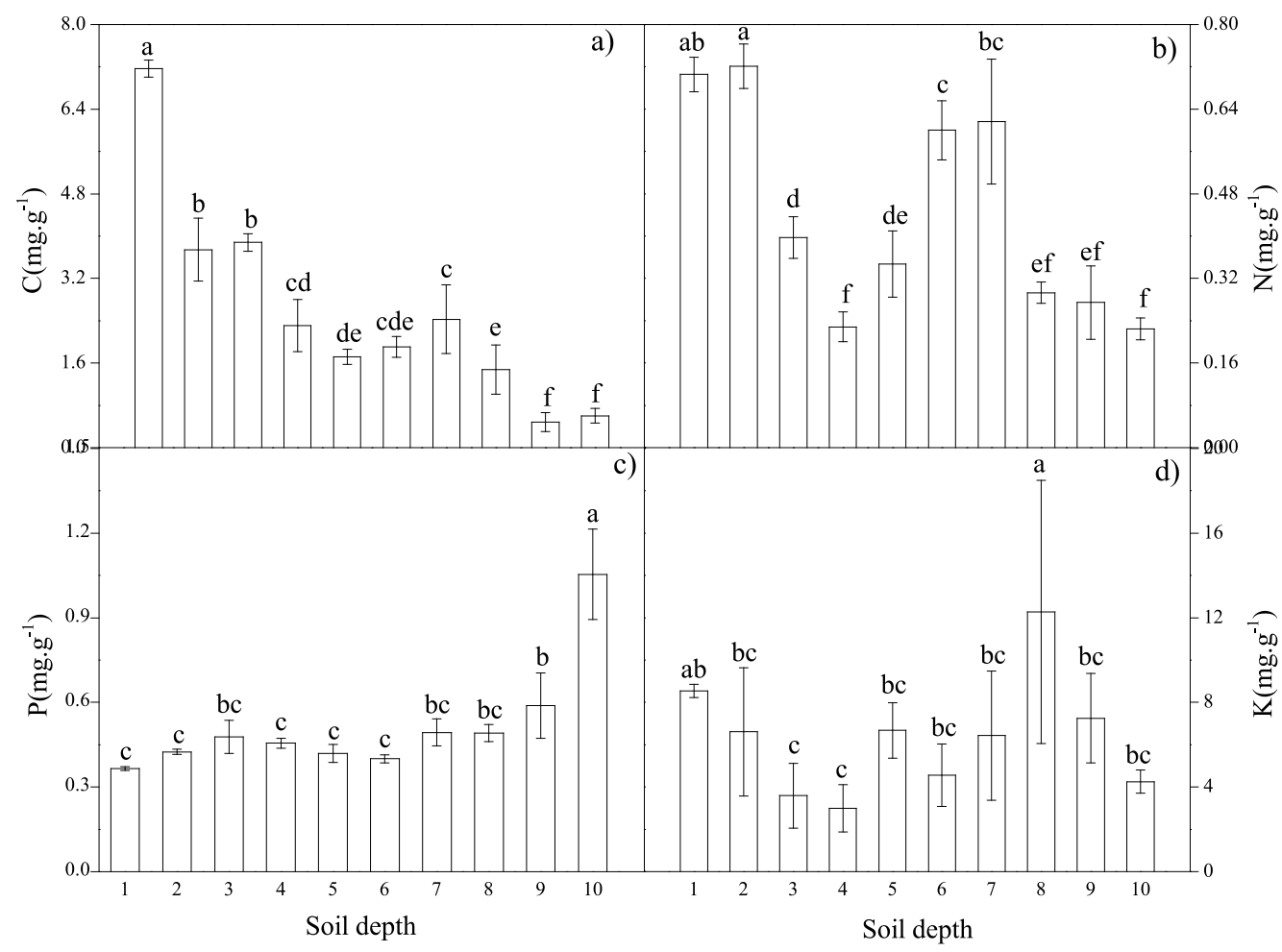

Fig. 1. SOC, total N, total P, and total K contents at different soil depths. From 1 to 10 represent 0-40, 40-80, 80-120, 120-160, 160-200, 200-240, 240-280, 280-320, 320-360, and 360-400 cm. Values are the mean \pm standard deviation of ten layers, whereas letters of different case indicate significant differences among the treatments at $p<0.05$. The same below. 

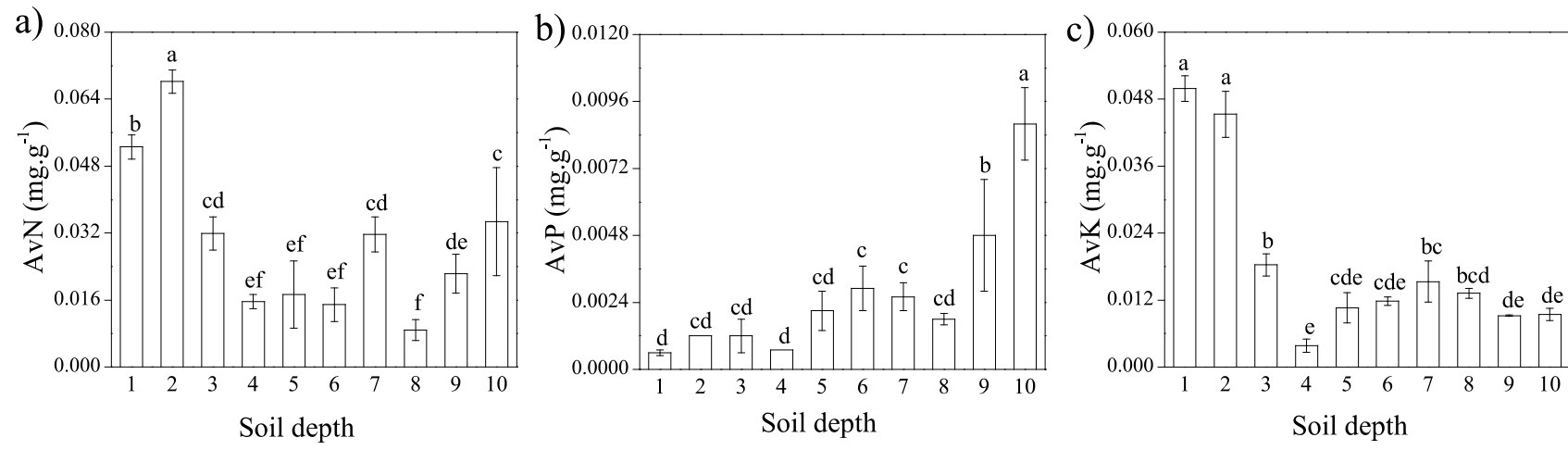

Fig. 2. Available N, P, and K contents at different soil depths.

higher at the surface than in the bottom layer. Total $\mathrm{N}$ fluctuated with soil depth (initial decrease, followed by an increase, then a decrease in the bottom layers); an abrupt change was found in the $240-280 \mathrm{~cm}$ layer. Total $\mathrm{P}$ varied between 0.36 and $1.05 \mathrm{mg} \mathrm{g}^{-1}$, with no significant changes in the $0-320 \mathrm{~cm}$ depth range and with highest values found in the bottom layer. Total $\mathrm{K}$ varied between 3.00 and $9.43 \mathrm{mg} \mathrm{g}^{-1}$, with higher levels occurring at the surface and bottom layers; however, no clear trend was observed with increasing soil depth, and large fluctuations occurred between different layers.

The available $\mathrm{N}$, available $\mathrm{P}$, and available $\mathrm{K}$ contents of soil at different depths are presented in Fig. 2. Available $\mathrm{N}$ fluctuated (decrease, increase, decrease, increase) with soil depth, and high values of $0.05,0.07$, and $0.08 \mathrm{mg} \mathrm{g}^{-1}$ were found in the $0-40$, $40-80$, and $360-400 \mathrm{~cm}$ soil layers, respectively. Available $\mathrm{P}$ generally increased with soil depth, but the supply capacity was relatively low. Available K fluctuated (decrease, increase, decrease) with soil depth.

\section{Nutrient Supply Intensity of Soil at Different Depths}

The nutrient supply intensity is indicative of the level of available nutrients in the soil. As Fig. 3 shows, the $\mathrm{N}$ supply intensity was generally higher in the upper than in the bottom layer; however, it reached $27.88 \%$ in the $160-200 \mathrm{~cm}$ soil layer. The P supply intensity was generally lower toward the surface, with minimum values observed in the $120-160 \mathrm{~cm}$ layer $(0.15 \%)$. This is consistent with the trend of available $\mathrm{P}$, indicating that $\mathrm{P}$ was derived from parent material and migrated at a low rate. The $\mathrm{K}$ supply intensity was relatively high in the surface layer, while lower levels with little fluctuation were found at $>120 \mathrm{~cm}$ soil depth.

\section{Ecological Stoichiometric Characteristics of Soil at Different Depths}

The SOC, N, P and $\mathrm{K}$ stoichiometric ratios of soil across different depths were statistically analyzed (hereinafter $\mathrm{N}, \mathrm{P}$, and $\mathrm{K}$ refer to total content). As shown in Fig. 4, the $\mathrm{C}: \mathrm{N}$ ratio ranged from 1.83 to 10.17 and showed a downward trend with the increase of soil depth. The C:P ratio varied between 0.59 and 19.58 and gradually decreased as soil depth increased. The N:P ratio ranged from 0.21 to 1.93 and showed an abrupt increase in the $200-280 \mathrm{~cm}$ layer. The C:K ratio ranged from 0.06 to 0.94 and was higher in the 200-280 cm layer, with no obvious trend with soil depth. The N:K ratio ranged from 0.04 to 0.14 , with no clear trend between different layers; however, an abrupt increase occurred in the $200-280 \mathrm{~cm}$ layer. The P:K ratio varied between 0.04 and 0.16 and it first increased and then decreased in the vertical direction. a)

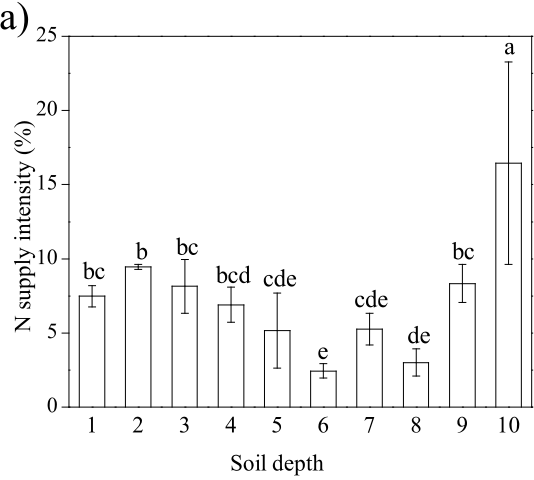

b)

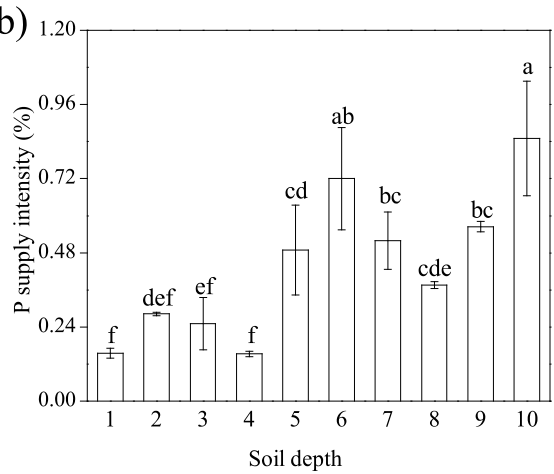

c)

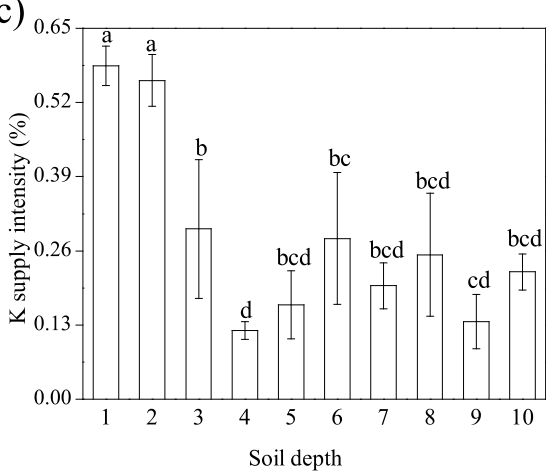

Fig. 3. Nutrient supply intensity of soil at different depths. 

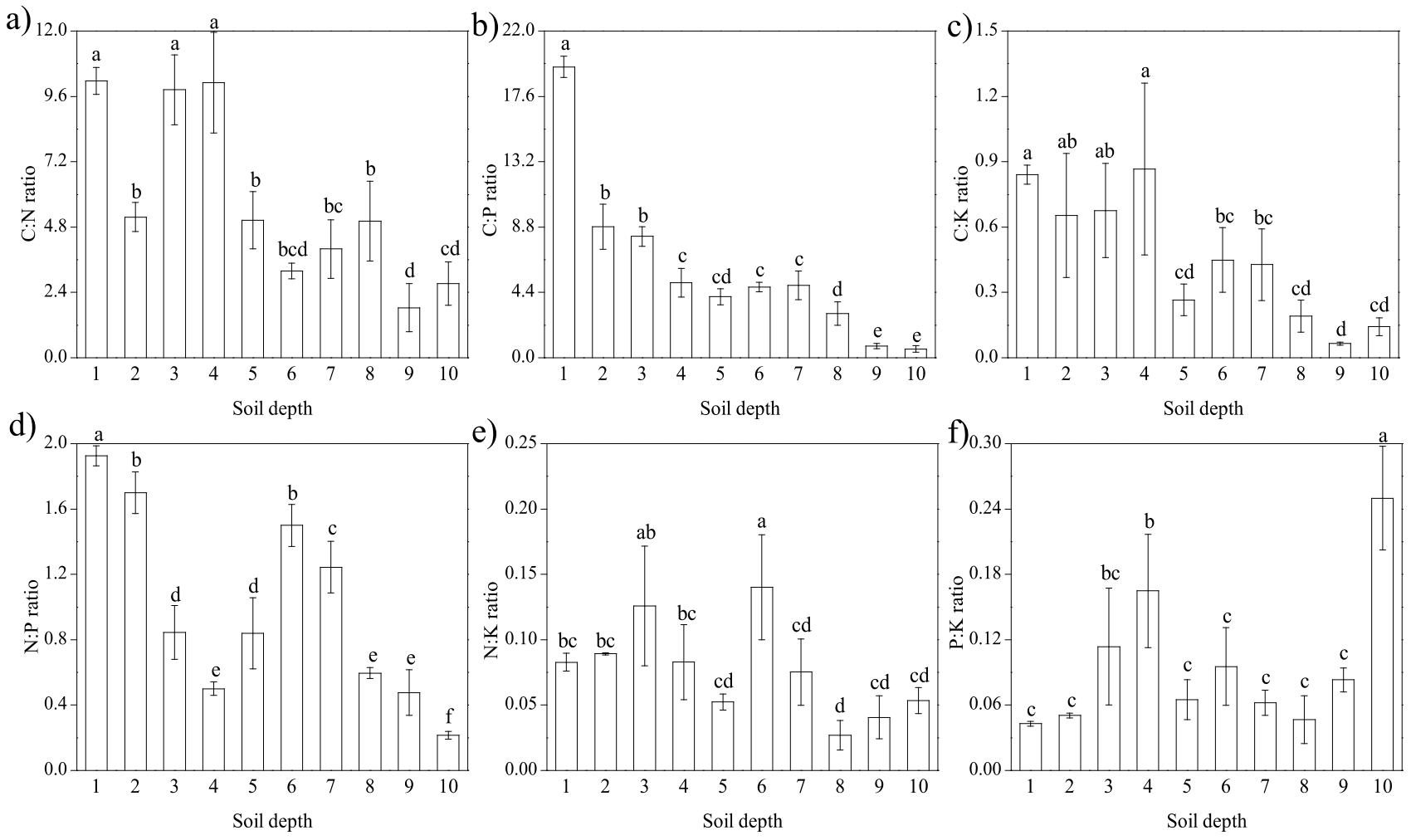

Fig. 4. Stoichiometric ratios of SOC, N, P, and K at different soil depths.

\section{Correlations between Ecological Stoichiometric Ratios and Nutrient Supply Intensity}

The correlation analysis presented in Table 1 describes the correlations between the ecological stoichiometric ratios and the nutrient supply intensity. The correlation between the C:N, C:P, or C:K ratios and $\mathrm{P}$ supply intensity fitted to a power function. The correlation between the $\mathrm{C}: \mathrm{P}, \mathrm{C}: \mathrm{K}, \mathrm{N}: \mathrm{P}$, or $\mathrm{N}: \mathrm{K}$ ratios, and $\mathrm{K}$ supply capacity fitted to a cubic equation with one unknown. The correlation between the P:K ratio and $\mathrm{N}$ supply intensity fitted to a quadratic equation with one unknown.

\section{Correlations between Soil Nutrient Content and Stoichiometric Ratios}

As shown in Table 2, there was a significant positive correlation between soil C:K vs. N:P $(p<0.05)$. A highly significant positive correlation was found between SOC vs. N, C:N, C:P, and N:P, C:K; N vs. C:P, N:P, and $\mathrm{N}: \mathrm{K}$; P vs. P:K; C:N vs. C:P; C:P vs. N:P; N:P vs. N:K; and $\mathrm{C}: \mathrm{K}$ vs. $\mathrm{C}: \mathrm{N}, \mathrm{C}: \mathrm{P}$ and $\mathrm{N}: \mathrm{K}(p<0.01)$. There was a significant negative correlation between SOC vs. P:K; P vs. $\mathrm{C}: \mathrm{N}$ and $\mathrm{C}: \mathrm{K} ; \mathrm{C}: \mathrm{P}$ vs. $\mathrm{P}: \mathrm{K}$; and $\mathrm{K}$ vs. $\mathrm{C}: \mathrm{K}(p<0.05)$. A highly significant negative correlation was found between SOC vs. P; N vs. P and P:K; P vs. C:P and N:P; and $\mathrm{K}$ vs. $\mathrm{N}: \mathrm{K}(p<0.01)$.

Table 1. Relationship between ecological stoichiometric ratios and nutrient supply intensity.

\begin{tabular}{|c|c|c|c|c|}
\hline $\mathrm{y}$ & $\mathrm{x}$ & Equation & $\mathrm{R}^{2}$ & $\mathrm{P}$ \\
\hline $\mathrm{C}: \mathrm{N}$ & P supply intensity & $\mathrm{y}=-0.75 \mathrm{x}^{2.50}$ & 0.613 & 0.000 \\
\hline $\mathrm{C}: \mathrm{P}$ & P supply intensity & $\mathrm{y}=-1.20 \mathrm{x}^{1.36}$ & 0.550 & 0.000 \\
\hline $\mathrm{C}: \mathrm{P}$ & K supply intensity & $\mathrm{y}=-43.09 \mathrm{x}^{3}+165.43 \mathrm{x}^{2}-102.16 \mathrm{x}+5.81$ & 0.719 & 0.000 \\
\hline $\mathrm{C}: \mathrm{y}$ & P supply intensity & $\mathrm{y}=-0.99 \mathrm{x}^{0.15}$ & 0.516 & 0.000 \\
\hline $\mathrm{C}: \mathrm{K}$ & K supply intensity & $\mathrm{y}=0.36 \mathrm{x}^{3}+2.53 \mathrm{x}^{2}-1.84 \mathrm{x}+0.23$ & 0.426 & 0.002 \\
\hline $\mathrm{N}: \mathrm{P}$ & K supply intensity & $\mathrm{y}=-0.13 \mathrm{x}^{3}+6.44 \mathrm{x}^{2}-4.48 \mathrm{x}+0.60$ & 0.536 & 0.000 \\
\hline $\mathrm{N}: \mathrm{K}$ & K supply intensity & $\mathrm{y}=0.73 \mathrm{x}^{3}-1.38 \mathrm{x}^{2}+0.74 \mathrm{x}-0.004$ & 0.504 & 0.000 \\
\hline $\mathrm{P}: \mathrm{K}$ & N supply intensity & $\mathrm{y}=0.001 \mathrm{x}^{2}+0.08$ & 0.407 & 0.001 \\
\hline
\end{tabular}


Table 2. SOC, N, P, and K contents, stoichiometric ratios and their correlations.

\begin{tabular}{|c|c|c|c|c|c|c|c|c|c|c|}
\hline Index & SOC & $\mathrm{N}$ & $\mathrm{P}$ & $\mathrm{K}$ & $\mathrm{C}: \mathrm{N}$ & $\mathrm{C}: \mathrm{P}$ & $\mathrm{C}: \mathrm{K}$ & $\mathrm{N}: \mathrm{P}$ & $\mathrm{N}: \mathrm{K}$ & $\mathrm{P}: \mathrm{K}$ \\
\hline $\mathrm{SOC}$ & 1 & $0.67^{* *}$ & $-0.49^{* *}$ & 0.24 & $0.73^{* *}$ & $0.99^{* *}$ & $0.63^{* *}$ & $0.75^{* *}$ & 0.19 & $-0.42^{*}$ \\
\hline $\mathrm{N}$ & & 1 & $-0.48^{* *}$ & 0.19 & 0.09 & $0.67^{* *}$ & 0.33 & $0.97^{* *}$ & $0.52^{* *}$ & $-0.47^{* *}$ \\
\hline $\mathrm{P}$ & & & 1 & -0.11 & $-0.40^{*}$ & $-0.51^{* *}$ & $-0.43^{*}$ & $-0.62^{* *}$ & -0.31 & $0.70^{* *}$ \\
\hline $\mathrm{K}$ & & & & 1 & 0.03 & 0.23 & $-0.39^{*}$ & 0.18 & $-0.56^{* *}$ & $-0.70^{* *}$ \\
\hline $\mathrm{C}: \mathrm{N}$ & & & & & 1 & $0.68^{* *}$ & $0.73^{* *}$ & 0.20 & -0.00 & -0.15 \\
\hline $\mathrm{C}: \mathrm{P}$ & & & & & & 1 & $0.60^{* *}$ & $0.77^{* *}$ & 0.19 & $-0.43^{*}$ \\
\hline $\mathrm{C}: \mathrm{K}$ & & & & & & & 1 & $0.41^{*}$ & $0.61^{* *}$ & 0.13 \\
\hline $\mathrm{N}: \mathrm{P}$ & & & & & & & & & $0.50^{* *}$ & -0.53 \\
\hline $\mathrm{N}: \mathrm{K}$ & & & & & & & & & 1 & 0.24 \\
\hline
\end{tabular}

$* *$ :indicate highly significant differences at $\mathrm{P}<0.01$ level.

*:indicate significant differences at $\mathrm{P}<0.05$ level

\section{Discussion}

\section{Response of Organic C, N, P, K and their Ecological} Stoichiometric Characteristics to Soil Layer

In the karst plateau mountain area, soil depth is an important factor that determines the change of soil nutrient contents, and fractured soil nutrients play an important role in the material circulation and transfer, energy flow, and biogeochemical cycle of ecosystems. SOC and $\mathrm{N}$ are the most important indicators of soil quality and are also an important component of SOC and $\mathrm{N}$ pools, reflecting the soil fertility level and regional ecosystem evolutionary pattern [25]. The present study showed that SOC and N had large variations with soil depth, indicating a strong influence of soil depth on major soil nutrients. This is because SOC and $\mathrm{N}$ are influenced by soil parent material, litter decomposition, atmospheric sedimentation, and plant uptake and utilization, resulting in a large spatial variation [26]. The SOC and N were found to be higher in the surface soil, as the soil surface was in direct contact with the external environment, where surface litter, animal debris, plant roots, and microbial activities play an important role in the concentration of SOC and $\mathrm{N}$ at the soil surface [27]. The nutrients then migrate and diffuse toward the lower layers with water or other media, forming a gradual distribution pattern gradually decreasing from the surface to the lower soil layers [28]. Soil $\mathrm{P}$ and $\mathrm{K}$ showed little variation with the change of soil depth because these two nutrients are mainly affected by soil parent material [29] over a relatively long time period [8]. The C:N, N:P, N:K, and P:K ratios showed large variations because of the relative stability of $\mathrm{P}$ and $\mathrm{K}$ coupled with the large variability of SOC and $\mathrm{N}$. The stoichiometric parameters were mainly affected by SOC and N.

The availability of soil $\mathrm{N}$ and $\mathrm{P}$ nutrients is a major factor in regulating plant litter decomposition rate and ecosystem $\mathrm{C}$ balance. Table 3 shows that the soil $\mathrm{N}$ content in the study area was lower than those of previous studies conducted in karst peak-cluster depression and canyon areas, as well as lower than those in Yili wild fruit-tree forest and the national average of China, and comparable to results from the hilly and gully region of the Loess Plateau. This indicates that soil $\mathrm{N}$ was deficient in the study area, perhaps because of the small litter stock and large nutrient loss. Nutrient retention is closely associated with slope and surface rock coverage. In the karst plateau mountain area of China, the large slope and low surface rock coverage are likely to accelerate nutrient loss and are not conducive to nutrient preservation. This study showed that $\mathrm{P}$ had little variation and remained relatively stable in the karst plateau mountain area, which may be because soil $\mathrm{P}$ is mainly derived from weathering of rock with a relatively constant $\mathrm{P}$ content. With regard to $\mathrm{P}$ content, the average $\mathrm{P}$ content of the Earth's crust is $2.8 \mathrm{~g} \mathrm{~kg}^{-1}$, and the average soil $\mathrm{P}$ content of China is $0.56 \mathrm{~g} \mathrm{~kg}^{-1}$ [30]. The soil $\mathrm{P}$ content in the present study area was relatively low, possibly owing to the higher precipitation $(863 \mathrm{~mm})$ and greater leaching loss compared with the national scale. In summary, there were different degrees of $\mathrm{N}$ and $\mathrm{P}$ limitation in the soil profile of the study area, which improved nutrient use efficiency but highlighted the issue of insufficient nutrient supply.

Nutrients represent an important factor affecting the structure and function of ecosystems. Nutrient supply amounts and its coordination affect organism growth, population structure, species succession, and ecosystem stability [31]. The C:N ratio of soil from the karst plateau mountain area of China was lower than the national average (10-12) and the global average (14.3). Soil with a lower C:N ratio is subject to accelerated microbial decomposition and rapid mineralization [26, 32], perhaps because resource limitation improves nutrient use efficiency. This may be a mechanism for ecosystems to adapt to nutrient limitation, which drives the occurrence 


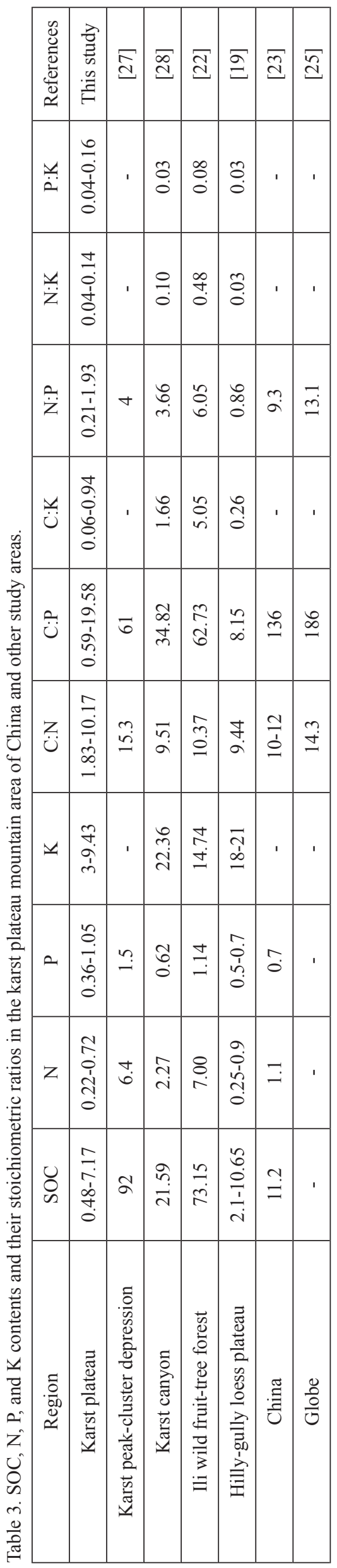

of ecosystems. The $\mathrm{C}: \mathrm{N}$ ratio is also a sensitive indicator of soil quality, affecting the cycling of SOC and $\mathrm{N}$ in soil, and determining the quality and rate of formation and accumulation of SOC. The results obtained in the present study showed that there were large differences in the C:N ratios of soil between different layers. This may be because the SOC and $\mathrm{N}$ sources were diverse and highly variable, displaying inconsistent responses to environmental changes; however, this is inconsistent with the conclusion that the $\mathrm{C}: \mathrm{N}$ ratio of different ecosystems is relatively stable [26]. It is possible that deeper soil layers did not directly provide nutrients for plant growth and was mineralized to relatively low levels. The variation patterns require in-depth study. We suggest studying the spatiotemporal evolution pattern of microbial $\mathrm{C}, \mathrm{N}$, and $\mathrm{P}$ relationships and their responses to land use change, revealing the regulation mechanism of $\mathrm{C}: \mathrm{N}$ stabilization, and exploring the strategy of $\mathrm{C}$ and $\mathrm{N}$ synergy.

The C:P ratio can be used to evaluate the mineralization ability of soil $\mathrm{P}$ and measure the ability of microorganisms to release $\mathrm{P}$ from soil organic matter by mineralization or absorb and immobilize $\mathrm{P}$ from the environment [33-35]. A low C:P ratio is beneficial for promoting microbial decomposition of organic matter and the release of nutrients and promote the increase of available $\mathrm{P}$ in soil, indicating high $\mathrm{P}$ availability. In contrast, a high C:P ratio can lead to competition between soil microorganisms and plants for soil inorganic $\mathrm{P}$, which is unfavorable to plant growth. The C:P ratio in our study area ranged from 0.59 to 19.58 , which is much lower than the national average of China (136) and the global average (186) [36]. This result indicates high $\mathrm{P}$ availability in the soil and may be attributed to the poor P nutrient levels in the study area. Improvements to the P-dissolution ability of plant roots in this area could be regarded as a potential future direction for ecological restoration, and the $\mathrm{P}$ utilization level of plant roots can be improved through human interventions and the system's internal regulation measures.

The soil N:P ratio can be used as a diagnostic indicator of $\mathrm{N}$ saturation and to determine the threshold for nutrient limitation [37]. The average soil N:P ratio in the study area was $0.21-1.92$, which is lower than the average of China (9.3), the global average (13.1) [38], and the karst peak-cluster depression in Guangxi, China [33]. The low soil N:P ratio in our study area indicates a high possibility of soil N deficiency. However, we should take this result objectively. In addition to the N:P ratio, we need to also study the growth status of vegetation and its nutrient utilization strategy to produce an integrated approach to the diagnosis of nutrient limiting relationships.

In this study, the contents of SOC, N, and $\mathrm{P}$ constantly varied with soil layer, but showed highly significant correlations with each other $(p \leq 0.01)$. This indicates mutual promotion among SOC, total $\mathrm{N}$, and total $\mathrm{P}$, while total $\mathrm{K}$ was not significantly correlated 
with the above three factors. The stoichiometry of soil nutrient provides a new perspective on SOC, N, and $\mathrm{P}$ cycling. The subjects selected in this study were limited, and in future research we should study the ecological stoichiometry of the plant-litter-soil continuum by combining the interactions of plants, litter, and soil, and their ecological stoichiometric relationships. The reason for the excessive standard deviation may be that the karst landform is a binary three-dimensional spatial regional structure, the karst environment is a large open system with complex structure, and the material and energy flow in a specific region has undergone dramatic evolution, development, balance and variation, which leads to high heterogeneity of habitat, so the content of elements varies greatly.

\section{Indicative Role of the SOC:N:P:K Ratio}

Soil $\mathrm{N}$ and $\mathrm{P}$ are the most common limiting elements in plant growth and profoundly influence various plant functions [38]. Soil C:N:P:K, as the ratio of SOC to total $\mathrm{N}, \mathrm{P}$, and $\mathrm{K}$ in organic matter, is an important indicator of the composition, quality, and concentration of soil organic matter. Numerous factors can affect the element contents and their stoichiometric ratios, including vegetation, age, climate, soil animals, and human activities, resulting in large changes of $\mathrm{C}: \mathrm{N}: \mathrm{P}: \mathrm{K}$ with depth. Wang et al. showed that there was a significant negative correlation between the rate of SOC decomposition and the $\mathrm{C}: \mathrm{N}$ ratio [39]. Thus, the C:N ratio can serve as an important indicator for predicting the rate of organic matter decomposition [40]. The C:N ratio in the study area was relatively low, indicating net mineralization of organic matter. Despite the high use efficiency of soil $\mathrm{P}$ in the study area, the available quantity was relatively low.

The karst rocky desertification area suffers serious soil degradation [41], with low fertility, weak water retention and storage capacity, unsynchronized water and fertilizer supply, and low ecological environment capacity. The conditions for plant growth are correspondingly poor. Additionally, the study area is located at a high altitude and in a cold habitat, where soil $\mathrm{N}$ and $\mathrm{P}$ are deficient; the plants therefore have developed strong adaptability, which may affect their growth rate and further influence the community structure and stability, leading to regressive succession. From the perspective of soil nutrient use, we therefore believe that improvement of soil nutrient level and ecosystem nutrient self-cycling ability is beneficial to ecological conservation in the karst plateau mountain area.

\section{Relationship between Soil Ecological Stoichiometric Ratios and Nutrient Supply Intensity}

Investigating the relationship between the ecological stoichiometric ratios and nutrient supply intensity of soil can reveal the self-regulation mechanism of nutrient balance and elucidate the synergistic mechanism of nutrients. Our results show that N, P, and K supply intensity had certain correlations to the ecological stoichiometric ratios. In particular, $\mathrm{P}$ and $\mathrm{K}$ supply intensity had a close relationship with ecological stoichiometric ratios. It is possible that the $\mathrm{P}$ and $\mathrm{K}$ sources were relatively stable and the ecosystem could achieve self-regulation, which highlights the importance of maintaining the ecosystem's self-stability.

Future studies should be strengthened in the following three aspects: (1) Litter is an important source of soil $\mathrm{N}$; the quality, quantity, and decomposition rate of litter are important factors affecting nutrient content and cycling [28]. However, in-depth study is needed to investigate how the decomposition process of litter affects soil ecosystem stoichiometric ratios and the nutrient supply intensity, which helps to understand the nutrient cycling patterns in forest ecosystems. (2) The growth of plant roots is constrained by the type and distribution of fractures in the karst area, thus influencing the soil nutrient supply capacity and ecological stoichiometric balance. However, related study reports are rare due to the difficulties of sampling. Therefore, it is crucial to determine an approach to study soil nutrient regulation ability in karst areas by combining fracture characteristics, plant type, and root architecture. (3) When studying the nutrient content and ecological stoichiometric characteristics of the deep soil, we should perform a systematic analysis in combination with geological structure and rock type in order to better reveal nutrient migration and variation patterns, which are helpful for developing nutrient acquisition strategies in vegetation restoration.

\section{Conclusion}

The results of this study showed that both soil $\mathrm{N}$ and $\mathrm{P}$ nutrients were deficient with insufficient supply capacity in the karst plateau mountain area of China. The nutrient supply capacity of $\mathrm{N}$ and $\mathrm{K}$ was higher in the surface layer, while the nutrient supply capacity of $\mathrm{P}$ was higher in deeper soils. There was certain coordination between nutrient supply intensity and ecological stoichiometric ratios. The soil nutrient level and the ecosystem's nutrient self-cycling capacity should be improved. The results of this study provide evidence for making full use of fractured soil nutrients in the karst plateau mountain area and contribute to the development of strategies for vegetation restoration.

\section{Acknowledgements}

The authors thank Professor Yonggui Wu (Guizhou University) for providing the experimental conditions. Funding support: Project of National Key Research and Development Program of China in the $13^{\text {th }}$ Five-year Plan 
(2016YFC0502601); the Sciand Tech Project of Guizhou Province, China, "Study on the Key Technology for construction and restoration of cold- and droughtresistant vegetation in the rocky desertification area" (Qian-ke-he LH[2016]7201); and the doctoral research project supported by Guizhou Normal University: "Adaptive restoration of cold- and drought-tolerant vegetation in the karst plateau mountain area"(2016). We thank Alex Boon, PhD, from Liwen Bianji, Edanz Group China (www.liwenbianji.cn/ac), for editing the English text of a draft of this manuscript.

\section{References}

1. KRAVKAZ KUSCU I.S., CETIN M., YIGIT N., SAVACI G., SEVIK H. Relationship between Enzyme Activity (Urease-Catalase) and Nutrient Element in Soil Use. Polish Journal of Environmental Studies 27 (5), 2107, 2018.

2. KRAVKAZ-KUSCU I.S., SARIYILDIZ T., CETIN M., YIGIT N., SEVIK H., SAVACI G. Evaluation of the Soil Properties and Primary Forest Tree Species in Taskopru (Kastamonu) District. Fresenius Environmental Bulletin 27 (3), 1613, 2018.

3. SEVIK H., CETIN M. Effects of water stress on seed germination for select landscape plants. Polish Journal of Environmental Studies 24 (2), 689, 2015.

4. CETIN M., SEVIK H., YIGIT N., OZEL H.B., ARICAK B., VAROL T. The variable of leaf micromorphogical characters on grown in distinct climate conditions in some landscape plants. Fresenius Environmental Bulletin 27 (5), 3206, 2018.

5. GUNEY K., CETIN M., GUNEY K.B., MELEKOGLU A. The Effects of Some Hormone Applications on Lilium martagon L. Germination and Morpholgical Characters. Polish Journal of Environmental Studies 26 (6), 2533, 2017.

6. CETIN M., SEVIK H. Measuring the Impact of Selected Plants on Indoor $\mathrm{CO}_{2}$ Concentrations. Polish Journal of Environmental Studies 25 (3), 973, 2016.

7. KAYA L.G., KAYNAKCI-ELINC Z., YUCEDAG C. CETIN M. Environmental outdoor plant preferences: a practical approach for choosing outdoor plants in urban or suburban residential areas in Antalya, Turkey. Fresen Environ Bull 27 (12), 7945, 2018.

8. ELSER J.J., STERNER R.W., GOROKHOVA E., FAGAN W.F., MARKOW T.A., COTNER J.B., HARRISON J.F., HOBBIE S.E., ODELL G.M., WEIDER L.W. Biological stoichiometry from genes to ecosystems. Ecology Letters 3 (6), 540, 2000.

9. ELSER J.J., FAGAN W.F., DENNO R.F., DOBBERFUHL D.R., FOLARIN A., HUBERTY A., INTERLANDI S., KILHAM S.S., MCCAULEY E., SCHULZ K.L. Nutritional constraints in terrestrial and freshwater food webs. Nature 408 (6812), 578, 2000.

10. ZHANG L.X., BAI Y.F., HAN X.G. Application of N:P stoichiometry to ecology studies. Acta Botanica Sinica $\mathbf{4 5}$ (9), 1009, 2003.

11. KOERSELMAN W., MEULEMAN A.F. The vegetation N:P ratio: a new tool detect the nature of nutrient limitation. The Journal of Applied Ecology 33 (6), 1441, 1996.

12. FAN H.B., WU J.P., LIU W.F., YUAN Y.H., HU L., CAI Q.K. Linkages of plant and soil C:N:P stoichiometry and their relationships to forest growth in subtropical plantations. Plant and Soil 392, 127, 2015.
13. CHI Y.K., XIONG K.N., CHEN H., MIN X.Y., LIAO J.J., SHEN X.Y. Effect of grazing to copper pollution meadow on copper metabolism in Wumeng semi-fine wool sheep. Polish Journal of Environmental Studies 28(3), 1,2019. DOI: $10.15244 /$ pjoes $/ 87102$

14. REDFIELD A.C. 1 The biological control of chemical factors in the environment. American Scientist 46 (6), 205, 958.

15. BRYAN S.G., ANNETTE S., MICHAEL B.C:N:P stoichiometry and nutrient limitation of the soil microbial biomass in grazed grassland site under experimental $\mathrm{P}$ limitation or excess. Ecological Processes 1, 1, 2012.

16. CHI Y.K., XIONG K.N., XIAO H., CHEN H., HUANG D.H., WEN Y.Q., SHEN X.Y. A comparative study on meat quality between Guizhou semi-fine wool sheep and a series of semi-fine wool sheep in southwest China. Fresenius Environmental Bulletin 27 (6), 4238, 2018.

17. EDWARD T.C., SOMERVILLE J.L. The C:N:P:S stoichiometry of soil organic matter. Biogeochemistry 130, $117,2016$.

18. MOOSHAMMER M., WANE K., SCHNECKER J., WILD B., LEITNER S., HOFHANSL F., BLOCHI A., AHMMERLE I., FRANK A.H. Stoichiometric controls of nitrogen and phosphorus cycling in decomposing beech leaf litter. Ecology93(4), 770, 2012.

19. LI A., GUO D.L., WANG Z.Q., LIU H.Y. Nitrogen and phosphorus allocation in leaves, twigs, and fine roots across 49 temperate, subtropical and tropical tree species: A hierarchical. Functional Ecology 24 (1), 224, 2010.

20. XIE J., CHANG S.L., ZHANG Y.T., WANG H.J., SONG C.C., HE P., SUN X.J. Plant and soil ecological stoichiometry with vertical zonality on the northern slope of the middle Tianshan Mountains. Acta Ecologica Sinica 36 (14), 4363, 2016.

21. LI D.W., WANG Z.Q., TIAN H.X., HE W.X., GENG Z.C. Carbon, nitrogen and phosphorus contents in soils on Taibai Mountain and their ecological stoichiometry relative to elevation. Acta Pedologica Sinica 54, 160,2017.

22. XIONG K.N., CHI Y.K., SHEN X.Y. Research on Photosynthetic Leguminous Forage in the Karst Rocky Desertification Regions of Southwestern China. Polish Journal of Environmental Studies 26( 5), 2319, 2017.

23. YUAN H., SHENG H., LIAO C. L., ZHOU Q., ZHANG Z.Y., XIE H.X., HUANG Y.X. Profile distribution of soil fertility factors in different types of paddy soils in Hunan Province. Chinese Agricultural Science Bulletin 30 (3), 151, 2014.

24. HE J.S., HAN X.G. Ecological stoichiometry: Searching for unifying principles from individuals to ecosystems. Chinese Journal of Plant Ecology 34 (1), 2, 2010.

25. ZHANG C.H., WANG Z. M., JU W. M., REN C. Y. Spatial and temporal variability of soil $\mathrm{C} / \mathrm{N}$ ratio in Sonnen plain maize belt. Environmental Science. 32 (5), 407, 2011.

26. ZHU Q.L., XING X.Y., ZHANG H., AN S.S. Soil ecological stoichiometry under different vegetation area on loess hilly-gully region. Acta Ecologica Sinica 33 (15), 4674, 2013.

27. LV J.L., YAN M.J., SONG B.L., GUAN J.H., SHI W.Y., DU S. Ecological stoichiometry characteristics of soil carbon, nitrogen, and phosphorus in an oak forest and a black locust plantation in the Loess hilly region. Acta Ecologica Sinica 37 (10), 3385, 2017.

28. LIU X.Z., ZHOU G.Y., ZHANG D.Q., LIU S.Z., CHU G.W., YAN J.H. N and P stoichiometry of plant and soil in lower subtropical forest successional series in southern China. Chinese Journal of Plant Ecology 34 (1), 64, 2010. 
29. TAO Y., ZHANG Y.M., ZHOU X.B. Ecological stoichiometry of surfaces oil nutrient and its influencing factors in the wild fruit forest in Yili region, Xinjiang, China. Chinese Journal of Applied Ecology 27, 2239, 2016.

30. TIAN H.Q., CHEN G.S., ZHANG C., JERRY M.M., CHARLES A.S. Pattern and variation of $\mathrm{C}: \mathrm{N}: \mathrm{P}$ ratios in china's soils: A synthesis of observational data. Biogeochemistry 98 (1-3), 139,2010.

31. SONG S.Z., XIONG K.N., CHI Y.K., SHEN X.Y., GUO T., LU N.N. Research progress and prospect of grassland establishment and ecological animal husbandry in the karst rocky desertification area. Fresenius Environmental Bulletin 27 (10), 7017, 2018

32. GUNTHER S., HOLGER K. Bulk soil $\mathrm{C}$ to $\mathrm{N}$ ratio as a simple measure of net $\mathrm{N}$ mineralization from stabilized soil organic matter in sandy arable soils. Soil Biology and Biochemistry 35 (4), 629, 2003.

33. ZENG Q.C., LI X., DONG Y.H., LI Y.Y., CHEN M., AN S.S. Ecological stoichiometry characteristics and physicachemical properties of soils at different latitueds on the Loess Plateau. Journal of Natural Resources 30, 870, 2015.

34. ZENG Z.X., WANG K.L., LIU X. L., ZENG F.P., SONG T.Q., PENG W.X., ZHANG H., DU H. Stoichiometric characteristics of plants, litter, and soils in karst plant communicities of Northwest Guangxi. Chinese Journal of Plant Ecology 39, 682, 2015.

35. FAN F.J., SONG T.Q., HUANG G.Q., ZENG F.P., PENG W.X., DU H., LU S.Y., SHI W.W., TAN Q.J. Characteristics of spatial variation of soil nutrients in sloping field in a gorge karst region, southwest China. Chinese Journal of Applied Ecology 25 (1), 92,2014.

36. ZHAO F.Z., SUN J., REN C.J., DENG J., HAN X.H., YANG G. H., FENG Y.Z., REN G.G. Land use change influences soil C, N, P Stoichiometry under 'Grain-to Green Program's' in China. Scientific Reprots 5, 1, 2015.

37. ZHAO F.Z., KANG D., HAN X.H., YANG G.H., FENG Y.Z., REN G.X. Soil stoichiometry and carbon storage in long-term afforestation soil affected by understory vegetation diversity. Ecological Engineering 74, 415, 2015.

38. REICH P.B., WALTERS M.B., ELLSWORTH D.S. From tropics to tundra: Global convergence in plant functioning. Proceedings of the National Academy of Sciences of the United States of America 94 (25), 13730, 1997.

39. SHEN X.Y., CHI Y.K., HUO B., WU T., XIONG K.N. Effect of fertilization on rye grass quality and mineral metabolism in grazing the Wumeng semi-fine wool sheep $[\mathrm{J}]$. Fresenius Environmental Bulletin 27 (10), 6824, 2018.

40. ELSER J.J., ACHARY K., KYLE M., COTNER J., MAKINO W., MARKOW T., WATTS T., HOBBIE S., FAGAN W., SCHADE J., HOOD J., STERNER R. W.Growth rate-stoichiometry couplings in diverse biota. Ecology Letters 6 (10), 936, 2003.

41. CAO J.H., YUAN D.X., TONG L.Q., AZIM M., YANG H., HUANG F. An overview of karst ecosystem in southwest China: current state and future management. Journal of Resources and Ecology 6 (4), 247, 2015. 